ISLAMIC BANKING Volume 3 Nomor 1 Edisi Agustus $2017 \mid 11$

\title{
TINJAUAN FIQH MUAMALAH TERHADAP TIMBANGAN JUAL BELI KARET DI DESA BETUNG KECAMATAN LUBUK KELIAT KABUPATEN OGAN ILIR
}

\author{
Saprida \\ Sekolah Tinggi Ekonomi dan Bisnis Syariah (STEBIS) Indo Global Mandiri \\ Email: saprida@stebisigm.ac.id
}

\begin{abstract}
Abstrak
Penelitian ini berupaya menjawab beberapa masalah : Bagaimana pelaksanaan jual beli karet di desa Betung Kecamatan Lubuk Keliat Kabupaten Ogan Ilir, bagaimana tinjauan fiqih muamalah terhadap kecurangan jual beli karetdi desa Betung Kecamatan Lubuk Keliat Kabupaten Ogan Ilir. Sejalan dengan masalah yang telah dirumuskan, maka penelitian ini bertujuan untuk mengetahui pelaksanaan jual beli karetdi desa Betung Kecamatan Lubuk Keliat Kabupaten Ogan Ilir, untuk mengetahui tinjauan figh muamalah terhadap kecurangan jual beli karet di desa Betung Kecamatan Lubuk Keliat Kabupaten Ogan Ilir.

Untuk mengetahui masalah tersebut penulis menggunakan jenis data kualitatif, dengan sumber data primer yaitu merupakan data pokok yang diperoleh dengan menggunakan studi lapangan mewawancarai sebagian penjual dan pembeli karet yang melaksanakan jual beli karet di desa Betung. Sedangkan data sekunder diambil dari dokumentasi dan literatur yang berhubungan dengan masalah yang diteliti, seperti buku-buku perpustakaan yang ada kaitannya dengan permasalahan yang dibahas. Adapun teknik pengumpulan data yaitu observasi, wawancara dan dokumentasi. kemudian data yang telah terkumpul dianalisa secara kualitatif dengan menggunakan instrumen analisis deduktif interpretatif.

Dari penelitian ini ditemukan, bahwa pelaksanaan jual beli karet di desa Betung dilakukan setiap hari Rabu, ada yang menjual karet dengan sistem bebas dan ada pula yang menjual karet secara terikat pada toke karet. Dari hasil penelitian ada pembeli karet (toke karet) yang melakukan praktek kecurangan melalui timbangan karet dan ada sebagian penjual karet (petani karet) yang menambahkan batu dan tanah ke dalam kepingan karet untuk menambah berat timbangan ketika dijual. Dalam fiqh muamalah jual beli tersebut tidak sah karena bertentangan dengan syarat dan rukun jual beli yang telah ditetapkan dalam syariat Islam. Selain bertentangan dengan syariat Islam melakukan kecurangan merupakan perbuatan zalim kepada orang lain dalam urusan hartanya dan memakan harta mereka dengan cara yang batil. Walaupun hanya sedikit, harta yang didapatkan dengan jalan berbohong, menyembunyikan kecacatanatau mengurangi timbangan adalah harta yang haram.
\end{abstract}

Kata Kunci: Fiqh Muamalah, Jual Beli, Timbangan, Karet

\section{Dasar Pemikiran}

Manusia sebagai makhluk hidup mempunyai kebutuhan yang bersifat fisik dan non fisik. Kebutuhan itu tidak pernah dapat dihentikan selama hidup manusia. Untuk mencapai kebutuhan itu, satu sama lain saling bergantung. Manusia sebagai makhluk sosial tidak mungkin dapat hidup seorang diri. Manusia pasti memerlukan kawan atau 
orang lain. Oleh karena itu, manusia perlu saling hormat menghormati, tolong menolong dan saling membantu dan tidak boleh saling menghina, menzhalimi, dan merugikan orang lain.Dalam upaya menanamkan kepekaan untuk saling tolong menolong, kita dapat mebiasakan diri dengan menginfakkan atau memberikan sebagian rezeki yang kita peroleh meskipun sedikit, seperti memberikan santunan kepada fakir miskin, orang tua dan jompo, mengangkat anak asuh, memberi bantuan kepada orang yang sedang menuntut ilmu, membangun sarana umum (jalan), serta mencari upaya mengentaskan kemiskinan yang ada di masyarakat(Abdul, $1997: 32$ ).

Sebagai masyarakat pedesaan, bertani tentu merupakan suatu pekerjaan yang paling banyak dilakukan. Bertani merupakan suatu profesi bagi masyarakat khususnya masyarakat di desa Betung. Bertani bagi masyarakat desa Betung merupakan suatu pekerjaan yang sangat menjanjikan, sehingga orang yang mempunyai pekerjaan lain selain petani seperti guru, perangkat desa, pedagang dan lain sebagainya pun memiliki kebun. Begitu menjanjikannya kebun karet bagi masyarakat desa Betung tidak jarang mereka memiliki kebun karet berbidang-bidang bahkan sampai berhektar-hektar, karena bagi mereka penghasilan dari berkebun karet jauh lebih besar daripada penghasilan mereka dari mengajar, berdagang dan lain sebagainya.

Berdasarkan hasil wawancara dan pengamatan peneliti dalam pelaksanaan jual beli karet kadang-kadang didapati kesalahan-kesalahan, umpamanya di desa Betung, menurut pak Rozali (10 April 2017) yang bertugas sebagai kepala desa Betung II, dia menilai sebagian masyarakat kurang mengetahui syarat dan rukun jual beli yang benar menurut hukum Islam. Pada bulan April 2017, setelah diteliti ada pembeli karet (toke karet) yang melakukan praktek permainan (kecurangan) melalui timbangan karet. Pada bulan Mei tahun 2017, ada sebagian petani karet yang menambahkan batu dan tanah kedalam wadah getah karet yang sudah dicetak segi empat.

Berdasarkan latar belakang di atas, penulis mencoba untuk meneliti lebih lanjut tentang jual beli karet tersebut, penulis mencoba menuangkannya dalam sebuah jurnal yang berjudul: "Tinjauan Fiqh Muamalah Terhadap Timbangan Jual Beli Karet di Desa Betung Kecamatan Lubuk Keliat Kabupaten Ogan Ilir”. Dari jurnal ini diharapkan pelaksanaan jual beli karet di desa Betung bisa berjalan sesuai dengan syariat Islam, 
sehingga sistem jual beli karet bisa mempunyai kontribusi bagi kesejahteraan masyarakat di desa Betung.

\section{Tinjauan Pustaka}

Penelitian tentang jual beli telah banyak dilakukan.Penelitian yang berjudul "Praktik Jual Beli Karet (Studi kasus perdagangan karet di Kecamatan Haruai Kabupaten Tabalong)" ditulis oleh Irawati (2008) Penelitian ini dilatar belakangi oleh beberapa kasus jual beli karet yang dilakukan oleh petani karet dan pedagang karet. Pedagang karet yang memberikan pinjaman uang kepada petani karet dengan perjanjian dibayar dengan uang penjualan karet, sehinnga pedagang karet dapat menekan harga dan mengikat petani karet agar tidak menjual karet ke pedagang lainnya. Akibatnya petani karet ada yang untung ada yang rugi karena cara jual beli tersebut, sehingga perlu diteliti untuk dianalisis status hukumnya.Selanjutnya penelitian yang berjudul "Praktek jual beli karet di Kecamatan Gelumbang kabupaten Muara Enim ditinjau dari hukum Islam" yang ditulis oleh Marisa Farhana (2009) yang menjelaskan tentang hukum jual beli lelang dalam Islam.

Adapaun tulisan dalam bentuk buku antara lain, "Hadis Ekonomi (Ekonomi dalam Perspektif hadis Nabi)" (2015) yang membahas tentang pengertian jual beli, jual beli dalam perspektif hadis Nabi, rukun dan syarat jual beli, tujuan dan bentuk jual beli dan prinsip-prinsip jual beli. Selanjutnya "Fiqh Muamalah" (2010) yang membahas tentang dasar hukum jual beli, pengertian jual beli, rukun dan syarat jual beli bentuk-bentuk jual beli yang dilarang, manfaat dan hikmah jual beli dan melaksanakan jual beli yang benar dalam kehidupan.

\section{Pembahasan}

\section{Pengertian Jual Beli}

Secara terminologi, jual beli disebut dengan al-ba'i yang berarti menjual, mengganti, dan menukar sesuatu dengan sesuatu yang lainnya.Menurut Hanafiah pengertian jual beli ( $\left.a l-b a^{\prime} i\right)$ secara definitif yaitu tukar menukar harta benda atau sesuatu yag diinginkan dengan sesuatu yang sepadan melalui cara tertentu yang bermanfaat. Adapun menurut Malikiyah, Syafi'iyah dan Hanabilah bahwa jual beli (al- 
$14 \mid$ Saprida Tinjauan Fiqh Muamalah Terhadap.

ba'i) yaitu tukar menukar harta dengan harta pula dalam bentuk pemindahan milik dan kepemilikan(Ghazaly, dkk. 2010 : 67).

\section{Rukun Jual Beli}

Menurut pendapat Idri rukun jual beli yaituada penjual dan pembeli, ada shighat (lafal ijab dan kabul), ada barang yang dibeli, ada nilai tukar pengganti barang. Adapun syarat dari penjual dan pembeli yaitu berakal, tidak ada paksaan, baligh dan keduanya tidak mubadzir. Menurut kompilasi hukum ekonomi syar'ah, usur jual beli yaitu pihakpihak. Pihak-pihak yang terkait dalam perjanjian jual beli terdiri atas penjual, pembeli dan pihak lain yang terlibat dalam perjanjian tersebut.

Objek. Objek jual beli terdiri atas benda yang berwujud dan benda yang tidak berwujud, yang bergerak maupun benda yang tidak bergerak dan yang terdaftar maupun yang tidak terdaftar. Kesepakatan. Kesepakatan dapat dilakukan dengan tulisan, lisan dan isyarat, ketiganya mempunyai makna hukum yang sama. Ada dua bentuk akad, pertama yaitu akad dengan kata-kata, dinamakan juga dengan nama ijab kabul. Ijab yaitu kata-kata yang diucapkan terlebih dahulu. Misalnya : penjual berkata : "Baju ini saya jual dengan harga Rp 10.000,-. Kabul yaitu kata-kata yang diucapkan kemudian. Misalnya pembeli berkata : "Barang saya terima".Kedua yaitu akaddengan perbuatan, dinamakan juga dengan Mu'athah. Misalnya pembeli memberikan uang seharga Rp 10.000,- kepada penjual, kemudian mengambil barang yang senilai itu tanpa terucap kata-kata dari kedua belah pihak (Muhammad. 2010 : 34).

Menurut pendapat Abdul Rahman Ghazali, suatu jual beli tidak sah bila tidak memenuhi dalam suatu akad tujuh syarat, yaitu :

1. Saling rela antara kedua belah pihak, berdasarkan firman Allah dalam QS. AnNisa'/4: 29, dan hadist Nabi diriwayatkan oleh Ibnu Majah: "Jual beli haruslah atas dasar kerelaan (suka sama suka)."

2. Pelaku akad adalah orang yang dibolehkan melakukan akad, yaitu orang yang telah baligh, berakal dan mengerti.

3. Harta yang menjadi objek transaksi telah dimiliki sebalumnya oleh kedua belah pihak. Hal ini berdasarkan hadist Nabi SAW yang diriwayatkan olehAbu Daud dan Tirmizi. "Janganlah engkau menjual barang yang bukan milikmu”. 
4. Objek transaksi adalah barang yang dibolehkan dalam agama. Hal ini berdasarkan Hadist Nabi. "Sesungguhnya Allah bila mengharamkan suatu barang juga mengharamklan nilai jual barang tersebut."

5. Objek transaksi adalah barang yang biasa diserah terimakan. Hal ini berdasarkan hadist Nabi. “Dari Au Hurairah r.a bahwa Nabi Muhammad SAW melarang Jual beli gharar (penipuan).

6. Objek Jual beli diketahui oleh kedua belah pihak pada saat akad.

7. Harga harus jelas saat transaksi. Maka tidak sah jual beli dimana penjual mengatakan : "aku jual mobil ini kepadamu dengan harga yang akan kita sepakati nantinya”. Hal ini berdasarkan hadist Riwayar muslim tersebut.

\section{Dasar Hukum Jual Beli}

Jual beli sebagai sarana tolong menolong antara sesame umat manusia mempunyai landasan yang kuat dalam Al-Qur'an dan Sunah Rasulullah saw. Terdapat beberapa ayat Al-Qur'an dan Sunah Rasulullah saw tentang jual. yang berbicara tentang jual antara lain :

Al-Qur'an Al-Baqarah [2]: 198 : Artinya : Tidak ada dosa bagimu untuk mencari karunia (rezki hasil perniagaan) dari Tuhanmu. Maka apabila kamu telah bertolak dari 'Arafat, berdzikirlah kepada Allah di Masy'aril haram dan berdzikirlah (dengan menyebut) Allah sebagaimana yang ditunjukkan-Nya kepadamu dan sesungguhnya kamu sebelum itu benar-benar termasuk orang-orang yang sesat. (Q.S. Al-Baqarah 2 : 198).

\section{Pelaksanaan Jual Beli Karet Di Desa Betung.}

Pada umumnya masyarakat di desa Betung menjual hasil karetnya satu kali dalam satu minggu pada hari Rabu bertepatan dengan kalangan desa Betung. Mereka menampung terlebih dahulu hasil pekerjaan mereka. Pada waktu penjualan mereka kemudian menjual hasilnya tersebut dengan caranya masing-masing, ada yang menjual karet hasil kebunnya secara bebas ada pula yang menjual dengan sistem terikat karena sudah mengambil uang atau barang (berhutang) kepada salah satu pengumpul karet di desa tersebut. Berikut adalah uraiannya : 
16 | Saprida Tinjauan Fiqh Muamalah Terhadap................

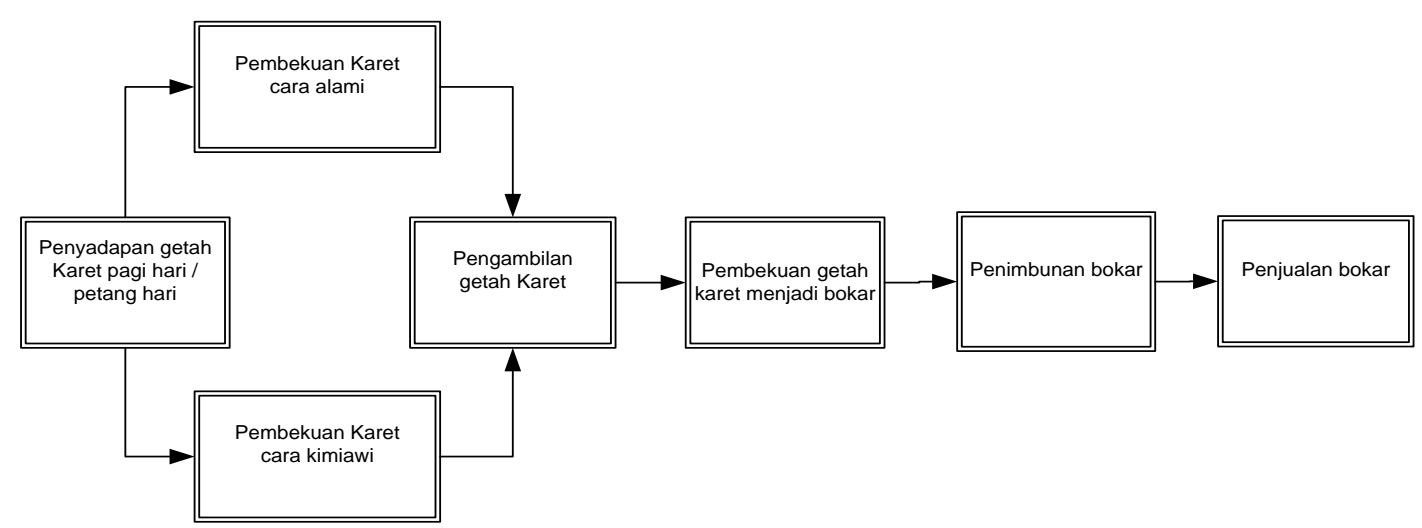

Diagram.3.1 Proses penyadapan getah karet di desa Betung

\section{Menjual Karet dengan Sistem Bebas}

Menjual karet dengan sistem bebas ini biasanya dilakukan oleh petani karet yang tidak terikat kepada salah satu bos atau yang biasa mereka sebut toke karet (pengumpul) di desa Betung. Biasanya orang yang menjual bebas ini adalah seseorang yang sudah cukup mampu untuk mengendalikan hasil karetnya dan mampu mencukupi ongkos atau kebutuhan sehari-hari, berupa sembako selama ia menyadap karet dan mengumpul hasilnya. Orang yang menjual bebas karet ini biasanya kepada orang-orang atau pembeli yang berasal dari desa Seri Kembang, desa Payaraman Kecamatan Tanjung Batu. Mereka ini biasanya membeli dengan harga yang lebih mahal dari pada pengumpulpengumpul yang ada di desa Betung dan mereka ini datang setiap hari rabu.

\section{Menjual Karet Dengan Sistem Terikat Pada Toke (Pengepul)}

Menjual karet secara sistem terikat ini dilakukan oleh sebagian petani karet dalam sistem transaksi jual-beli karet di desa Betung. Penjualan ini biasanya dilakukan dalam sistem durasi, misalnya satu minggu setiap kali bertimbang karet. Menurut seorang warga desa tersebut, ia menjual karet hasil kebunnya secara terikat karena ia sudah lebih dulu berhutang bahan-bahan makanan dan keperluan hidup lainnya. Dengan demikian ia harus melunasinya dengan harus menjual hasil karet kepada pengumpul atau toke tersebut. Namun dari seorang petani karet yang lain, penulis mendapat keterangan bahwa ada yang menjual karetnya secara terikat karena ia menyadap karet di kebun salah seorang toke atau pengumpul karet di desa tersebut. Memang kebiasaan di desa 
Betung setiap orang yang memiliki kebun karet dan mempekerjakan orang lain di kebun tersebut maka orang yang bekerja tersebut wajib untuk menjual hasil karetnya kepada si pemilik dengan durasi yang disepakati. (Hasil wawancara, 11April 2017).

\section{Pembagian Kualitas Getah Karet}

\section{Getah Karet Bersih}

Getah yang bersih mempunyai daya jual yang tinggi jika dibandingkan dengan getah kotor. Getah bersih adalah getah yang tidak tercampuri oleh tatal (tatal adalah nama atau sebutan untuk kulit pohon karet yang terkelupas akibat disadap). Oleh sebagian petani karet, tatal ini difungsikan untuk mempercepat proses pembekuan getah karet cair. Caranya, tatal tersebut dimasukan ke dalam tempurung atau mangkuk tempat penadah tetesan getah seiring dengan tetesan getah ke dalam mangkuk tersebut. Selain dengan menggunakan cuka, cara ini cukup efektif karena membutuhkan waktu singkat dan bersamaan dengan kecepatan petani dalam menyadap pohon karet. Apalagi disaat musim hujan (masa tersulit bagi petani karet) karena jika hujan turun pada saat getahgetah dalam mangkuk penadah belum membeku, maka sia-sialah kerja keras kita dalam seharian menyadap ribuan pohon karet dalam lahan kebun tersebut.

\section{Getah Karet Kotor}

Kebalikan dari getah bersih, harga getah kotor sangat rendah, malah jika kotornya keterlaluan, para pembeli getah tidak akan mau membeli produk getah tersebut. Getah kotor adalah getah yang di dalamnya banyak terdapat tatal dan kotoran yang lain seperti pasir, tanah, kayu. Adanya pasir, kayu dan yang lainnya di dalam getah bisa berasal dari rasa curang si pemilik getah agar getahnya memiliki berat yang lebih dari yang seharusnya, atau bisa juga karena kejadian alam, semisal hujan dan sebagainya.

Jadi, untuk memperoleh harga getah yang tertinggi, getah tersebut selain kering juga harus bersih. Sedang untuk produktifitas dan berat, bisa diatasi dengan penanganan dan perawatan yang baik, misalnya dengan pemupukan dan selalu berusaha agar pohon karet tidak cacat dan sebagainya. Penyadapan yang dilakukan setiap hari juga tidak bagus untuk produksi getah, karena lama-kelamaan getah cair yang dihasilkan akan lebih banyak memiliki kandungan air dari pada kandungan getahnya. Idealnya penyadapan dilakukan lima kali dalam satu minggu. (Hasil wawancara,15 Mei 2017). 
18 | Saprida Tinjauan Fiqh Muamalah Terhadap................

\section{Kesepakatan dalam Transaksi Jual Beli Karet di Desa Betung}

Pada umumnya dalam setiap transaksi penjualan dan pembelian karet memerlukan penimbangan untuk penetapan harga perkilunya sesuai harga pasaran karet di tingkat petani, berdasarkan penelitian penulis, para pembeli karet baik pengumpul yang di desa maupun pembeli-pembeli yang dari luar seperti Payaraman, Lubuk Keliat, toke karet memberlakukan berat netto dengan pemotongan berat sekitar $1 \%$ hingga $2 \%$ dari bruto sebagai kompensasi susut terhadap karet milik petani atau bisa juga ketika proses penimbangan ada berat pecahan perkilu selalu tidak dihitung, misalnya berat suatu karet ketika ditimbang 40,3 $\mathrm{kg}$ maka tercatat dalam transaksi adalah $40 \mathrm{~kg}$.

Penetapan harga karet ditingkat petani dan toke karet ada empat katagori yang mempunyai harga berbeda yaitu:

1. Harga karet kering bersih

2. Harga karet basah bersih

3. Harga karet kering kotor

4. Harga karet basah kotor

Dari empat katagori harga tersebut para penjual dan pembeli karet di desa Betung sepakat menjual dan membeli dengan harga karet "basah bersih" dengan sistem jual bebas dan sistem jual keterikatan kepada toke karet yang transaksinya diadakan setiap hari Rabu satu minggu sekali.

Berikut tabel transaksi jual beli karet di bulan April 2017:

\begin{tabular}{|l|c|c|c|c|c|}
\hline No & $\begin{array}{c}\text { Nama } \\
\text { Pembeli }\end{array}$ & $\begin{array}{c}\text { Minggu } \\
\text { Pertama }\end{array}$ & $\begin{array}{c}\text { Minggu } \\
\text { Kedua }\end{array}$ & $\begin{array}{c}\text { Minggu } \\
\text { Ketiga }\end{array}$ & $\begin{array}{c}\text { Minggu } \\
\text { Keempat }\end{array}$ \\
\hline 1 & Pak Rusdi & $4523 \mathrm{~kg}$ & $4288 \mathrm{~kg}$ & $3907 \mathrm{~kg}$ & $4053 \mathrm{~kg}$ \\
\hline 2 & Pak Hipni & $5120 \mathrm{~kg}$ & $3724 \mathrm{~kg}$ & $3571 \mathrm{~kg}$ & $3872 \mathrm{~kg}$ \\
\hline 3 & Pak Kutni & $3795 \mathrm{~kg}$ & $5036 \mathrm{~kg}$ & $4013 \mathrm{~kg}$ & $4360 \mathrm{~kg}$ \\
\hline 4 & Pak Arlin & $5230 \mathrm{~kg}$ & $3503 \mathrm{~kg}$ & $3859 \mathrm{~kg}$ & $3917 \mathrm{~kg}$ \\
\hline 5 & Pak Junaidi & $4193 \mathrm{~kg}$ & $5103 \mathrm{~kg}$ & $4130 \mathrm{~kg}$ & $5290 \mathrm{~kg}$ \\
\hline \multicolumn{2}{|l|}{ Total Transaksi } & $\mathbf{2 2 8 6 1} \mathbf{~ k g}$ & $\mathbf{2 1 6 5 4} \mathbf{~ k g}$ & $\mathbf{1 9 4 8 0 ~ k g}$ & $\mathbf{2 1 4 9 2} \mathbf{~ k g}$ \\
\hline
\end{tabular}

Tabel.3.1 Transaksi jual beli karet di bulan April 2017 


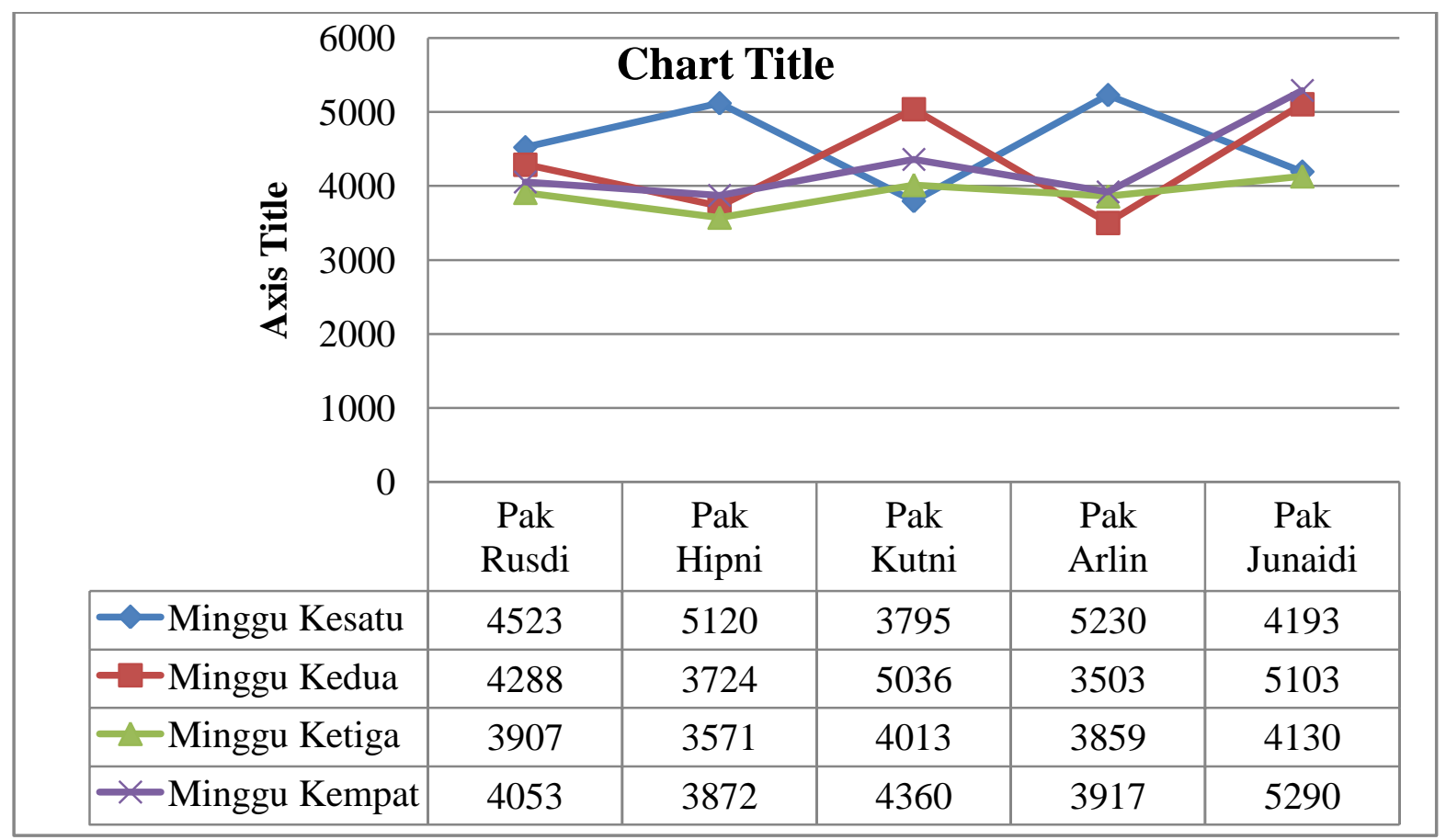

Grafik.3.1 Transaksi jual beli karet di bulan April 2017

Dari keterangan tabel dan grafik di atas terlihat jelas selisih transaksi jual beli karet setiap minggunya terutama pada munggu ketiga penyusutan yang sangat jauh, hal ini lazim terjadi karena disebabkan beberapa faktor biasanya yang membuat penyusutan jual beli karet yaitu pertama, faktor hujan membuat getah karet yang telah dibekukan di pohonnya menjadi rusak, kedua faktor kemarau, ketiga faktor adat dimana setiap ada kegiatan atau acara keramaian warga, misalnya pernikahan atau persedekahan adat membuat para petani karet tidak melakukan penyadapan karet dikarenakan adanya nilai toleransi sesama warga untuk membantu kegiatan tersebut(Hasil wawancara, 16Mei 2017).

Berdasarkan persepsi penjual dan pembeli karet di desa Betung dapat disimpulkan bahwa sebagian masyarakat desa Betung melakukan transaksi jual beli karet setiap hari Rabu dengan harga yang telah ditentukan oleh toke karet. Sebagian penjual karet ada yang menjual secara langsung datang ke rumah toke karet, ada yang menjual di pasar mingguan dan ada juga toke karet (pembeli karet) yang membeli karet ke rumah petani karet (penjual karet). Harga yang ditentukan oleh toke karet tidak menentu setiap minggunya, adakalanya tinggi dan adakalanya rendah berkisaran dari harga 5000 
sampai 7000 / kg. Petani karet merasa kesulitan dengan harga yang ditetapkan oleh toke karet yang terlalu rendah dan selalu berubah-rubah. Penetapan dari toke karet tersebut membuat sebagian petani karet melakukan kecurangan dengan cara menambahkan tanah atau batu ke dalam kepingan karet untuk menambah berat timbangan karet ketika dijual, mereka mengetahui perbuatan tersebut sangat merugikan toke karet tetapi mereka tidak menghiraukan kerugian yang dialami toke karet mereka beranggapan toke karet juga merugikan petani karet dengan cara melakukan kecurangan dalam timbangan karet. Minimnya pengetahuan sebagian penjual dan pembeli akan rukun dan syarat jual beli yang disyariatkan Islam membuat mereka melakukan kecurangan dalam jual beli karet.

\section{Praktek Kecurangan transaksi jual beli karet di Desa Betung}

Dalam hal jual beli karet di desa Betung sering kali ditemukan oknum penjual maupun membeli yang melakukan transaksi dengan cara curang, biasanya kecurangan yang dilakukan penjual karet adalah menambah berat karet dengan memasukkan benda ke dalam bokar atau kepingan karet tersebut baik itu berupa batu atau tanah. Sedangkan kecurangan oknum pembeli karet adalah dengan cara permainan timbangan (dacing) yaitu dengan mengebor dan memasukkan timah sebagai pemberat tambahan pada buah timbangan penghitung atau mengurangi berat buah timbangan kalibrasi pada timbangan stick (dacing gantung), dan ada juga kecurangan pembeli karet dengan cara mengurangi berat anak timbangan pada timbangan duduk.

Gambar timbangan yang sering dipakai oleh pembeli karet karet adalah sebagai berikut:

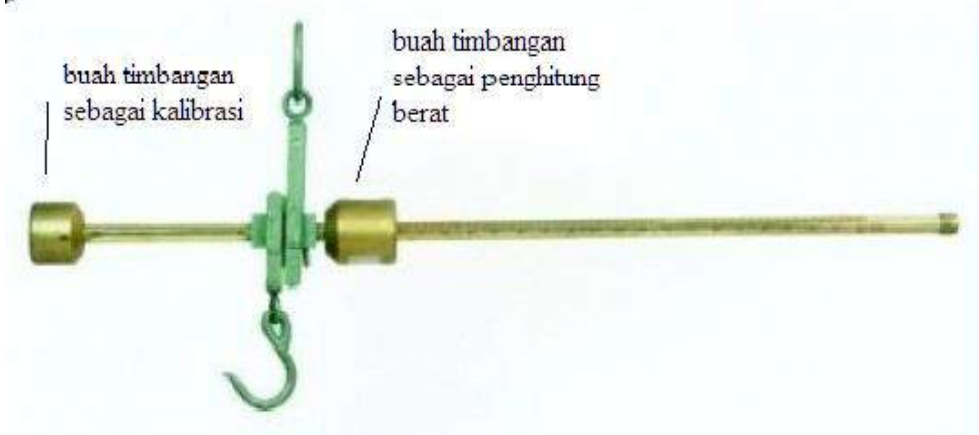

Gambar.4.3 Timbangan Stick (Timbangan gantung) 


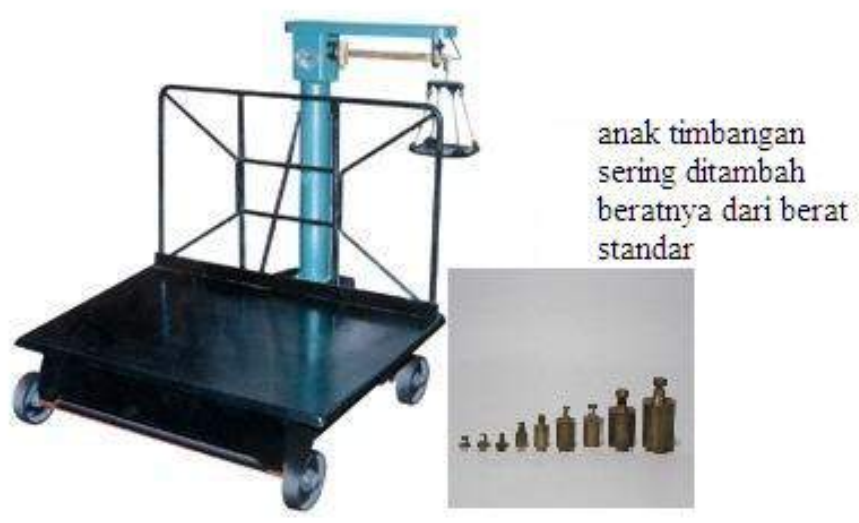

Gambar.4.4 Timbangan Duduk

Demikian gambaran realita yang terjadi di dalam transaksi jual-beli karet di desa Betung. Praktek permainan harga itulah yang akan ditinjau dari segi fiqh muamalah. Allah SWT, telah menjadikan manusia masing-masing saling membutuhkan satu sama lain, supaya mereka tolong menolong, tukar menukar keperluan dalam segala urusan kepentingan hidup masing-masing, baik dengan jalan jual beli, sewa menyewa, bercocok tanam, atau perusahaan yang lain, baik dalam urusan kepentingan sendiri maupun untuk kemaslahatan umum.

Dengan cara demikian kehidupan masyarakat menjadi teratur dan subur, pertalian yang satu dengan yang lain pun menjadi teguh. Akan tetapi sifat tamak manusia yang suka mementingkan diri sendiri, supaya hak masing-masing jangan sampai tersia-sia dan juga menjaga kemaslahatan umum agar pertukaran dapat berjalan dengan lancar dan teratur. Oleh sebab itu, agama memberi peraturan yang sebaik-baiknya karena dengan teraturnya muamalah, maka penghidupan manusia jadi terjamin pula dengan sebaik-baiknya sehingga perbantahan dan saling dendam tidak akan terjadi (Rasjid, 1994 : 278).

\section{Tinjauan Fiqh Muamalah Terhadap Kecurangan Jual Beli Karet di Desa Betung}

Muamalah secara harfiyah berarti pergaulan atau hubungan antar manusia. Dalam pengertian harfiyah yang bersifat umum ini, muamalah berarti perbuatan atau pergaulan manusia di luar ibadah. Muamalah merupakan perbuatan manusia dalam menjalin 
hubungan atau pergaulan antar sesama manusia sedangkan ibadah merupakan hubungan manusia dengan Tuhan (Mas'adi, $2002:$ 1).

Muamalah merupakan salah satu wadah atau wahana untuk meningkatkan taraf hidup. Dalam bidang muamalah, Islam mengatur dalam hubungan yang sedemikian rupa mengenai usaha kerjasama yang harus dilakukan atau ditempuh manusia baik melalui jalur, pinjam meminjam, jual beli, utang piutang dan lain sebagainya. Muamalah dalam pengertian luas adalah ketetapan yang diberikan oleh Tuhan yang langsung berhubungan dengan kehidupan sosial manusia, terbatas pada yang pokokpokok saja. Penjelasan Nabi, kalaupun ada, tidak pula terinci seperti halnya dalam bidang ibadah. Karena itu terbuka sifatnya untuk dikembangkan melalui ijtihad manusia yang memenuhi syarat untuk melakukan usaha. Karena sifatnya yang demikian, dalam soal muamalah berlaku asas umum yakni pada dasarnya semua perbuatan boleh dilakukan, kecuali kalau mengenai perbuatan itu ada larangan di dalam Al-Quran dan Al-Hadits yang memuat Sunnah Nabi Muhammad SAW, (Ali, 2005 : 55).

Objek pembahasan fiqh muamalah adalah hubungan antara manusia dengan manusia lain yang berkaitan dengan benda atau mal. Hakikat dari hubungan tersebut adalah berkaitan dengan hak dan kewajiban antara manusia yang satu dengan manusia yang lain. Contohnya, seperti hak penjual untuk menerima uang pembayaran atas barang yang dijualnya, dan hak pembeli untuk menerima barang yang dibelinya. Adanya hak penjual untuk menerima uang pembayaran tersebut diiringi dengan adanya kewajiban untuk menyerahkan barang yang dijualnya kepada pembeli. Sebaliknya adanya hak pembeli untuk menerima barang yang dibelinya, juga diiringi dengan kewajiban untuk menyerahkan uang atas harga barang yang dibelinya kepada penjual. Hak dan kewajiban dua orang yang melakukan transaksi diatur sedemikian rupa dalam fiqh muamalah, agar setiap hak sampai kepada pemiliknya, dan tidak ada orang yang mengambil sesuatu yang bukan haknya. Dengan demikian, hubungan antara manusia yang satu dengan yang lainnya terjalin dengan baik dan harmonis, karena tidak ada pihak-pihak yang merugikan dan dirugikan (Muslich, 2010 : 3).

Fiqh muamalah adalah ilmu tentang hukum-hukum syara' yang mengatur hubungan manusia dengan manusia lain yang sasarannya harta benda atau mal. Hubungan tersebut sangat luas karena mencakup hubungan antara sesama manusia, baik muslim maupun 
non muslim. Namun ada beberapa prinsip acuan dan pedoman secara umum untuk kegiatan muamalah ini. Salah satunya adalah muamalah harus didasarkan kepada persetujuan dan kerelaan kedua belah pihak dan dalam muamalah tidak boleh merugikan diri sendiri dan orang lain. Persetujuan dan kerelaan kedua belah pihak yang melakukan transaksi merupakan asas yang sangat penting untuk keabsahan setiap akad. Untuk menunjukkan adanya kerelaan dalam setiap akad atau transaksi dilakukanlah ijab dan qabul atau serah terima antara kedua pihak yang melakukan transaksi. Setiap transaksi dan hubungan perdata (muamalah) dalam Islam juga tidak boleh menimbulkan kerugian kepada diri sendiri dan orang lain (Muslich, 2010 : 3-7).

Hukum Islam adalah hukum yang mengatur segala perbuatan manusia, baik itu ibadah maupun sosial. Kegiatan sosial merupakan salah satu aspek muamalah dari sistem Islam, sehingga kaidah fiqh yang digunakan dalam mengidentifikasikan transaksi-transaksi sosial juga menggunakan kaidah fiqh muamalah. Fiqh secara etimologi adalah mengerti atau paham, secara terminologi fiqh adalah pengetahuan tentang hukum syariah Islamiyah yang berkaitan dengan perbuatan manusia yang telah dewasa dan berakal sehat yang diambil dari dalil-dalil terperinci (Syafi'i 2004 : 14).

Islam memang menghalalkan usaha perdagangan, perniagaan dan atau jual beli. Namun tentu saja untuk orang yang menjalankan usaha perdagangan secara Islam, dituntut menggunakan tata cara khusus, ada aturan mainnya yang mengatur bagaimana seharusnya seorang Muslim berusaha di bidang perdagangan agar mendapatkan berkah dan ridha Allah SWT di dunia dan akhirat.Aturan main perdagangan Islam, menjelaskan berbagai etika yang harus dilakukan oleh para pedagang Muslim dalam melaksanakan jual beli. Dan diharapkan dengan menggunakan dan mematuhi etika perdagangan Islam tersebut, suatu usaha perdagangan dan seorang Muslim akan maju dan berkembang pesat lantaran selalu mendapat berkah Allah SWT di dunia dan di akhirat. Etika perdagangan Islam menjamin, baik pedagang maupun pembeli, masing-masing akan saling mendapat keuntungan (Idri, 2015: 155).

Allah SWT menurunkan syariat (hukum) Islam untuk mengatur kehidupan manusia, baik selaku pribadi maupun selaku anggota masyarakat. Hukum Islam melarang perbuatan yang pada dasarnya merusak kehidupan manusia, sekalipun itu 
disenangi oleh manusia atau sekalipun umpamanya perbuatan itu dilakukan hanya oleh seseorang tanpa merugikan orang lain (Usman, 2001 : 65).

\section{Perbuatan Curang dalam Jual Beli}

Berbuat curang dalam jual beli berarti berbuat zalim kepada orang lain dalam urusan hartanya dan memakan harta mereka dengan cara yang batil. Walau pun hanya sedikit, harta yang didapatkan dengan jalan berbohong, menyembunyikan kecacatan, atau mengurangi timbangan adalah harta yang haram. Sudah seharusnya kita menjauhkan diri kita dari harta-harta semacam itu.Nabi saw berangkat bersama rombongan para sahabat ke pasar untuk melakukan pengecekan barang-barang dagangan. Saat itu beliau melewati gundukan makanan, kemudian beliau memasukkan tangannya dan mendapati bagian dalam dari gundukan itu basah. Beliau berkata, "apa ini wahai penjual makanan?" Ia berkata, "bagian ini terkena air hujan wahai Rasulullah." beliau bersabda: Artinya : "Mengapa engkau tidak meletakkannya di bagian atas, agar orang yang akan membeli dapat melihatnya? Barangsiapa yang berbuat curang kepada kami, maka ia bukan bagian dari golongan kami." (HR Muslim).

Kecurangan dapat diatasi jika dalam hati masyarakat sudah tertanam dengan kuat nilai-nilai ketauhidan dan keimanan. Kesadaran selalu diawasi oleh Allah akan membuat seseorang tidak akan berani melakukan perbuatan tersebut. Pemahaman terhadap akibat-akibat buruk yang akan menimpa mereka kelak dari perbuatan curang harus terus ditingkatkan. Jika kesadaran ini telah terkolektif, maka insya Allah praktekpraktek kecurangan dapat dihilangkan, atau sedikitnya diminimalisir. Begitu juga halnya dengan pelaksanaan jual beli karetyang ada di desa Betung, setelah diteliti, ada toke karet yang malakukan kecurangan melalui timbangan karet, begitu juga dengan perbuatan sebagian petani karet yang melakukan kecurangan dengan menambahkan tanah dan batu ke dalam karet yang sudah dicetak kepingan. padahal perbuatan tersebut sangat merugikan petani karet dan jelas perbuatan tersebut sangat dilarang oleh ajaran Islam.

Dari uraian di atas sudah jelas bahwasanya Islam mengatur hubungan sesama manusia dengan sebaik mungkin. Bagaimana cara memperlakukan pekerja dengan baik, 
bagaimana dalam suatu transaksi tidak ada pihak yang merasa dirugikan, bagaimana antara hak dan kewajiban harus saling terpenuhi, semuanya diatur dalam Islam yakni melalui muamalah. Akan tetapi keegoisan manusia menghapuskan aturan-aturan yang telah ditetapkan dalam Islam, antara hak dan kewajiban sudah tidak saling melengkapi. Ketika hak sudah terpenuhi maka kewajiban dilupakan dan inilah yang ada pada sebagian masyarakat desa Betung. Jelas perbuatan tersebut bertentangan dengan ajaran dalam Islam.

\section{Simpulan}

Setelah penulis menguraikan pembahasan dalam bab terdahulu, maka dapat diambil kesimpulan sebagai berikut:

1. Pelaksanaan jual beli karet di desa Betung dilakukan setiap hari Rabu, ada yang menjual karet dengan sistem bebas dan ada pula yang menjual karet secara terikat pada toke karet. Dari hasil penelitian ada sebagian pembeli karet (toke karet) yang melakukan praktek kecurangan melalui timbangan karet dan ada sebagian penjual karet (petani karet) yang menambahkan batu dan tanah ke dalam kepingan karet untuk menambah berat timbangan ketika dijual.

2. Dalam fiqh muamalah melakukan kecurangan dalam jual beli tidak sah karena bertentangan dengan syarat dan rukun jual beli yang telah ditetapkan dalam syariat Islam. Selain bertentangan dengan syariat Islam perbuatan kecurangan merupakanperbuatan zalim kepada orang lain dalam urusan hartanya dan memakan harta mereka dengan cara yang batil. Walau pun hanya sedikit, harta yang didapatkan dengan jalan berbohong, menyembunyikan kecacatanatau mengurangi timbangan adalah harta yang haram. 
26 | Saprida Tinjauan Fiqh Muamalah Terhadap................

\section{DAFTAR PUSTAKA}

Al-Quran dan Terjemahnya. 2000. Depag RI. Jakarta : Gema Risalah Press.

Ash Siddieqy, Tengku Muhammad. 1997. Fiqh Mu'amalah. Semarang: Pustaka Rizki Putra.

Azzam, Abdul Aziz Muhammad. 2010. Fiqh Muamalat. Jakarta: Amzah.

Djamali Abdul. 1997. Hukum Islam. Bandung: Mandar Maju.

Djuwaini, Dimyauddin. 2010. Pengantar Fiqh Muamalah. Yogyakarta : Pustaka pelajar.

Ghazaly, Abdul Rahman, dkk. 2012. Fiqh Muamalat. Jakarta : Kencana.

Ibrahim, T, Darsono. 2004. Penerapan Fikih. Solo: PT Tiga Serangkai Pustaka Mandiri.

Idri, 2015. HadisEkonomi (Ekonomi dalam perspektif hadis Nabi). Kencana : Jakarta.

Lubis, Suhrawardi K. dkk. Hukum Ekonomi Islam. 2012. Jakarta: Sinar Grafika. h. 153.

Muslich, Ahmad Wardi. 2015. Fiqh Muamalat. Jakarta: Amzah.

Pradja, Juhaja. 2012. Ekonomi Syariah. Bandung : Pustaka Setia.

Rahman Abdul, Ghazaly, dkk. 2010. Fiqh Muamalat. Jakarta: Kencana.

Rasjid, Sulaiman. 2012. Fiqh Islam. Bandung: Sinar Baru Algensindo.

\section{Internet}

https://www.google.com/search?q=pembagian+jual+beli+karet\&ie=utf-8\&oe=utf$\underline{8 \& c l i e n t=f i r e f o x-b-a b}$ diakses 10 Desember 2016 